\title{
Lasiodiplodia pseudotheobromae causes stem canker of Chinese hackberry in China
}

\author{
Lu Liang ${ }^{1} \cdot$ Huan $\mathrm{Li}^{1} \cdot$ Lifeng Zhou ${ }^{1} \cdot$ Fengmao Chen ${ }^{1}$
}

Received: 28 March 2019 / Accepted: 24 June 2019 / Published online: 11 October 2019

(C) The Author(s) 2019

\begin{abstract}
Chinese hackberry (Celtis sinensis Pers.) is an adaptable species widely growing in southern China. The symptoms of canker on stems of seedlings were discovered mid-July 2017 in Shuyang, Jiangsu Province. The diseased portions of the stems were dark brown due to discoloured xylem. Some seedlings showed symptoms of wilting, leaf fall, twig dieback, and tissue discolouration. The outbreak period was concentrated in July and August, suggesting that the disease spread during summer months. Possible fungal causal agents were isolated from naturally infected canker tissue and discoloured xylem. The isolate from xylem tissue with a high frequency (> 50\%) was named Ls7 type. Pathogenicity tests were carried out on 4-yearold seedlings. The symptoms of canker began to develop 20 days after inoculation with Ls7 isolate and by day 35, there were dark, enlarged longitudinal lesions. A phylogenetic tree of the isolate was developed using the internal transcribed spacer, elongation factor- $1 \alpha$ (tefl- $\alpha), \beta$-tubulin gene $(T U B)$ and RNA polymerase II subunit primer genes (RPB2). Based on morphological features and phylogenetic information, the pathogen was identified as Lasiodiplodia
\end{abstract}

Project funding: The work was supported by the National Key Research and Development Program of China (Grant Number: 2017YFD0600104).

The online version is available at http://www.springerlink.com.

Corresponding editor: Tao Xu.

Fengmao Chen

cfengmao@njfu.edu.cn

1 Co-Innovation Center for Sustainable Forestry in Southern China, College of Forestry, Nanjing Forestry University, Nanjing 210037, Jiangsu, People's Republic of China pseudotheobromae. This is the first report of L. pseudotheobromae causing canker on Chinese hackberry stems in China.

Keywords Botryosphaeriaceae $\cdot$ Plant pathogen $\cdot$ Tree disease

\section{Introduction}

Chinese hackberry (Celtis sinensis Pers.) is an important and widely planted ornamental tree species in China, Japan and Korea (Lee et al. 2019) and is tolerant of dry and nutrientpoor soils. The tender leaf, roots and bark of hackberry can reduce swelling, relieve pain, clearing away heat and toxic materials. It is also used as industrial materials and various furniture. Its rhizome fibers are strong and used in paper making, making ropes, artificial cotton and artificial fiber. The species has significant value in medicine and industry (Cao 2017). However, with increased planting, Chinese hackberry diseases are increasing and becoming more and more serious (Cacciola 2000; Berbegal et al. 2012; Luongo et al. 2015). Common diseases of Chinese hackberry are powdery mildew, stem and root rot, twig blight and leaf spot.

The Botryosphaeriaceae is a fungal family containing pathogens that cause canker disease of trees (Pavlic 2004). Lasiodiplodia species are members of the Botryosphaeriaceae and are widely found in tropical and subtropical regions (Phillips et al. 2013). Lasiodiplodia species causing disease of Chinese hackberry have not been found in China.

In the summer of 2017 in Shuyang, Jiangsu Province, a severe outbreak of Chinese hackberry disease appeared. The slightly sunken grey-black lesions enlarged longitudinally and the associated weakening of tree vigor affected the ornamental and commercial value of the species. 
The objectives of this study were to: (1) discover the epidemiology of canker occurring on Chinese hackberry; (2) prove the pathogenicity of the fungal pathogen using Koch's Postulates Test; and (3) identify the causal agent using morphological and molecular techniques.

\section{Materials and methods}

\section{Sampling and fungal isolations}

In mid-July 2017, symptoms of stem canker were found in commercial nurseries located in Shuyang County, Suqian City, Jiangsu Province $\left(118^{\circ} 36^{\prime} 48^{\prime \prime} \mathrm{E} ; 34^{\circ} 15^{\prime} 25^{\prime \prime} \mathrm{N}\right)$. The entire infected 4 -year-old seedlings were brought to the laboratory for isolation of the pathogen.

Two ends of the cankers with spots in the middle were cut to form a small segment of $50 \mathrm{~mm}$, and treated under aseptic conditions. The samples were sterilized in $75 \%$ alcohol for $3 \mathrm{~min}$, dried quickly under a flame and rinsed three times with aseptic water for $30 \mathrm{~s}$. Aseptic filter paper was used to absorb the water on the surface. The tissues were cut into $4 \times 4 \mathrm{~mm}$ pieces between symptomatic and healthy tissues and cultured on fresh potato dextrose agar (PDA) medium containing $100 \mu \mathrm{g} \mathrm{mL}^{-1}$ ampicillin (Dai et al. 2007; Correia et al. 2016).

Samples were cultured at $25{ }^{\circ} \mathrm{C}$ in a dark incubator. Colony and spore morphologies were recorded every $24 \mathrm{~h}$ using a Nikon DS-Ri1 camera, Stereo Discovery, V20, Zeiss. The length and width of conidia were measured and the means, standard deviations and $95 \%$ reliable intervals computed from 50 samples.

\section{Pathogenicity tests}

Sixty fungal samples were divided into different groups according to colony morphology and ITS (internal transcribed spacer) sequences. All the isolate groups were tested for pathogenicity on the seedling stems. Each group was cultured for 7 days at $25{ }^{\circ} \mathrm{C}$ in darkness. Ten healthy Chinese hackberry seedlings (from 'Yanguan chunxiao farm'; Jiaxing City, Zhejiang Province $30^{\circ} 27^{\prime} 21^{\prime \prime} \mathrm{N}$, $120^{\circ} 32^{\prime} 40^{\prime \prime} \mathrm{E}$ ) were inoculated with each type of fungal isolates, respectively. Each plant was stabbed by placing a 4-mm-diameter mycelium plug of PDA placed face-down on each puncture wound. An additional ten seedlings were inoculated with sterilized PDA agar blocks as controls. All inoculated seedlings were kept in a greenhouse at $25^{\circ} \mathrm{C}$ under ambient conditions of 70-80\% humidity, with $24 \mathrm{~h}$ light every day. The experiment was carried out during the summer of 2018.

\section{DNA extraction and sequence amplification}

Fungal isolates were cultured in PDA medium for 5 days at $25{ }^{\circ} \mathrm{C}$. Genomic DNA was extracted from mature mycelia according to Zhang et al. (2008). The procedure was: (1) mycelium grown for 3-4 days was placed in $2 \mathrm{~mL}$ test tubes with $500 \mu \mathrm{L}$ of $2 \times \mathrm{CTAB}$ (containing $1 \%$ $\beta$-mercaptoethanol), rapidly cooled for $30 \mathrm{~s}$ in liquid nitrogen, and then heated immediately to $65^{\circ} \mathrm{C}$ for $30 \mathrm{~s}$. This was repeated three times; (2) a $1 / 2$ volume of glass beads was added to each test tube before placing on a vortex shaker for $4-5 \mathrm{~min}$, followed by heating to $65^{\circ} \mathrm{C}$ for $20 \mathrm{~min}$ and shaking once every $10 \mathrm{~min}$. Equal amounts of phenol: chloroform: isoamyl alcohol (25:24:1, v:v:v) were added and the tubes centrifuged at 12,000/min for $10 \mathrm{~min}$; (3) two volumes of pre-cooled absolute ethanol was added to the supernatant, mixed well and the tubes placed in stand still for 20-30 min at $20{ }^{\circ} \mathrm{C}$ followed by centrifuging for $10 \mathrm{~min}$ at $12,000 \mathrm{r} /$ min. The supernatant was poured out and $200 \mu \mathrm{L}$ of $70 \%$ alcohol was added to wash the DNA pellet, which was then dried at room temperature. One hundred $\mu \mathrm{L}$ TE was added to completely dissolve the DNA; and, (4) $100 \mu \mathrm{L}$ of RNase A $(10 \mathrm{mg} / \mathrm{mL})$ was attached to each tube and dried at $65^{\circ} \mathrm{C}$ for $30 \mathrm{~min}$. Step 3 was repeated and $30 \mu \mathrm{L}$ of $\mathrm{dd}_{2} \mathrm{O}$ was added to obtain a solution of the DNA.

The polymerase chain reaction amplification system (PCR; $50 \mu \mathrm{L}$ ) contains $25 \mu \mathrm{L}$ Etaq pre-Mix, $4 \mu \mathrm{L}$ DNA template (approximately $200 \mathrm{ng}$ ), $2 \mu \mathrm{L}$ forward primer, $2 \mu \mathrm{L}$

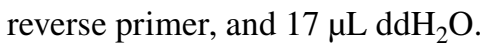

Four pairs of primers were selected to amplify the target gene: ITS-1 and ITS-4 (ITS) (White et al. 1994); EF1-688F and EF1-1251R (tefl- $\alpha$ ) (Alves et al. 2008); Bt2a and Bt2b (TUB) (Glass and Donaldson 1995); and, RPB2-LasF and RPB2-LasR (RPB2) (Cruywagen et al. 2016).

The PCR reaction procedure had the following steps: (1) initial denaturation at $95{ }^{\circ} \mathrm{C}$ for $5 \mathrm{~min}$; (2) denaturation at $95^{\circ} \mathrm{C}$ for $30 \mathrm{~s}$, (3) annealing at $55^{\circ} \mathrm{C}$ for $30 \mathrm{~s}$ and extending at $72{ }^{\circ} \mathrm{C}$ for 33 cycles; and (4) extending at $72{ }^{\circ} \mathrm{C}$ for $10 \mathrm{~min}$. However, the annealing temperature of $T U B$ and $R P B 2$ was $52{ }^{\circ} \mathrm{C}$ (Alves et al. 2004).

DNA amplification and sequencing were carried out with a GStorm Gradient PCR (Mastercycler nexus GSX1) using a program according to Zhang et al. (2008). The PCR products were sequenced by GenScript Biotechnology in Nanjing, China. To avoid errors in sequencing, DNA strands were spliced using forward and reverse primers (Two-way measurement: Sequencing Complete Sequences from Two Directions).

\section{Phylogenetic analyses}

The resulting ITS, tefl- $\alpha, T U B$ and $R P B 2$ gene sequences were blasted. Other sequences needed were obtained from 
the GenBank database of NCBI (https://www.ncbi.nlm.nih. gov). These sequences were aligned using MEGA version 5.0. Ambiguously aligned regions were excluded and gaps were treated as missing data. The phylogenetic tree was constructed using the Neighbor-Joining (NJ) approach (Tamura et al. 2011), which was validated using bootstrap analyses with 1000 repetitions (Saitou and Nei 1987). The phylogenetic tree was based on the concatenated sequences of ITS, tefl- $\alpha, T U B$ and $R P B 2$.

\section{Results}

\section{Incidence of the disease and symptoms}

In the summer of 2016, a small amount of Chinese hackberry canker disease occurred but did not attract attention in Suqian City. However, by mid-July 2017, the incidence of Chinese hackberry canker was high with symptoms of the disease in over $21 \%$ of the $6000 \mathrm{~m}^{2}$ of plantations of the species. The canker disease reappeared again in late July and August as well as spread rapidly.

The initial sites of infection appeared as watery reddish brown spots (Fig. 1a), and the top young leaves on twigs were wrinkled and brittle due to dehydration (Fig. 1b). With the development of the disease, slightly concave canker spots extended and gradually turned black-brown (Fig. 1c).

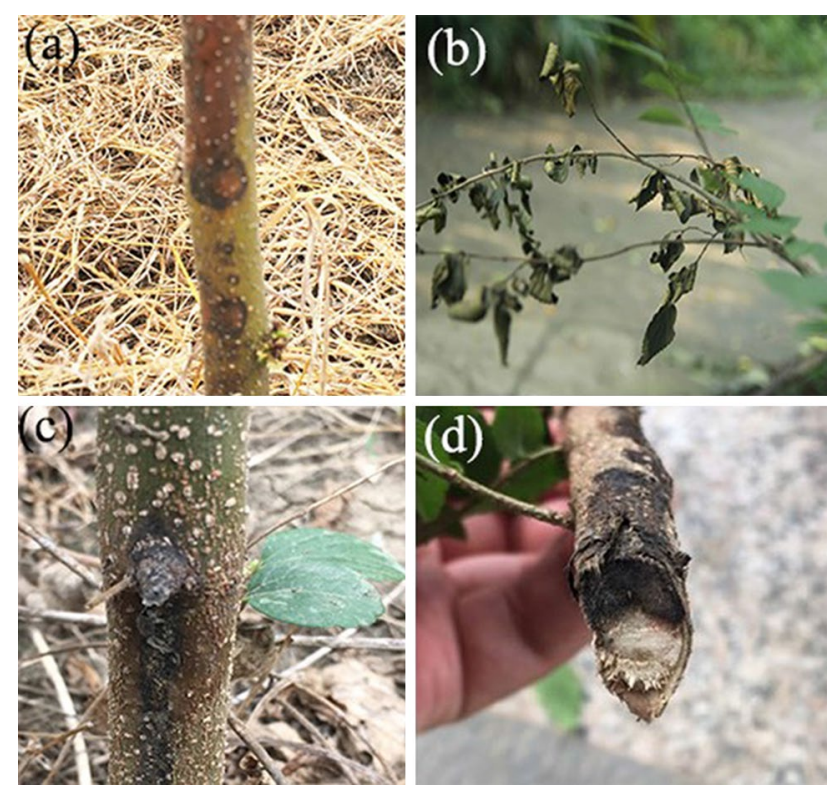

Fig. 1 Disease symptoms observed on Chinese hackberry in Shuyang, Jiangsu. a Stem blotch and canker in the beginning. b The leaves of the diseased plant showed dieback. c Canker spots extended longitudinally in the later stages of the canker disease. d Lesions in the inner stem of a diseased plant
Transverse sections of xylem tissue were also black-brown (Fig. 1d). Eventually, the twigs wilted.

\section{Fungal isolations and pathogenicity tests}

Sixty fungal samples were divided into seven types numbered Ls1 to Ls7 type according to colony morphology. Among these, more than 50\% were classified as Ls7 type and found to be similar to Lasiodiplodia pseudotheobromae. According to the ITS sequence, Ls1-Ls7 types were identified as Fusarium tricinctum (2\%), Diaporthe spp. (3\%), Clonostachys rosea (8\%), Alternaria alternaria (11\%), Fusarium equiseti (12\%), Rhizoctonia solani (14\%) and $L$. pseudotheobromae (50\%).

In mid-June 2018, each of the seven types of fungi was inoculated to 4-year-old seedlings with 10 replicates. After 20 days, eight seedlings inoculated Ls7 isolate showed disease symptoms similar to those that appeared in the field, including local, spindle-shaped necrosis and slightly concave red-brown spots (approximately $25 \mathrm{~mm} \times 5 \mathrm{~mm}$ ) (Fig. 2b). Two seedlings inoculated with Ls7 isolate developed canker spots on days 23 and 27 after inoculation, respectively. After 35 days, the lesions on these seedlings spread longitudinally on the stem, gradually changed shape from round to fusiform and became slightly concave. The lesions were approximately $98 \mathrm{~mm} \times 6 \mathrm{~mm}$ (Fig. 2c, d). These dark brown lesions contained pycnidia densely packed with conidia, and leaves on the twigs began to wilt (Fig. 2c). The xylem was also dark brown (Fig. 2e). Seedlings inoculated with sterile PDA showed no symptoms of canker (Fig. 2a) and resembled the Ls1-Ls6 isolates.

The fungus was recovered from the symptomatic inoculated tissues and the culture's characteristics and morphology were similar to the Ls7 isolate. Therefore, the Ls7 isolate was determined to be the pathogen, although the seedlings infected with Ls7 isolate did not die.

\section{Morphological characteristics of pathogen}

Colonies of the Ls7 isolate grew rapidly, and after 3 days of culturing at $25{ }^{\circ} \mathrm{C}$, were grayish-white with uneven edges (Fig. 3a). The colonies turned dark gray after 5 days (Fig. 3b), at which stage aerial hyphae were thick and fluffy. Following 2 weeks of treatment under UV light, the colonies produced pycnidia (Fig. 3c, d). There were many short conidiophores on the inner walls and conidia on the conidiophores. The pycnidia were nearly spherical, approximately 220-240 $\mu \mathrm{m}$ diameter, and formed scattered, unilocular, dark-brown to black areas on the stem and host epidermis (Fig. 4a). Conidiogenous cells were hyaline, cylindrical and holoblastic (Fig. 4c). Conidiophores were inflated at their base with one diaphragm which reduced to conidiogenous cells (Fig. 4d, e). Conidia were oval, both ends round and 


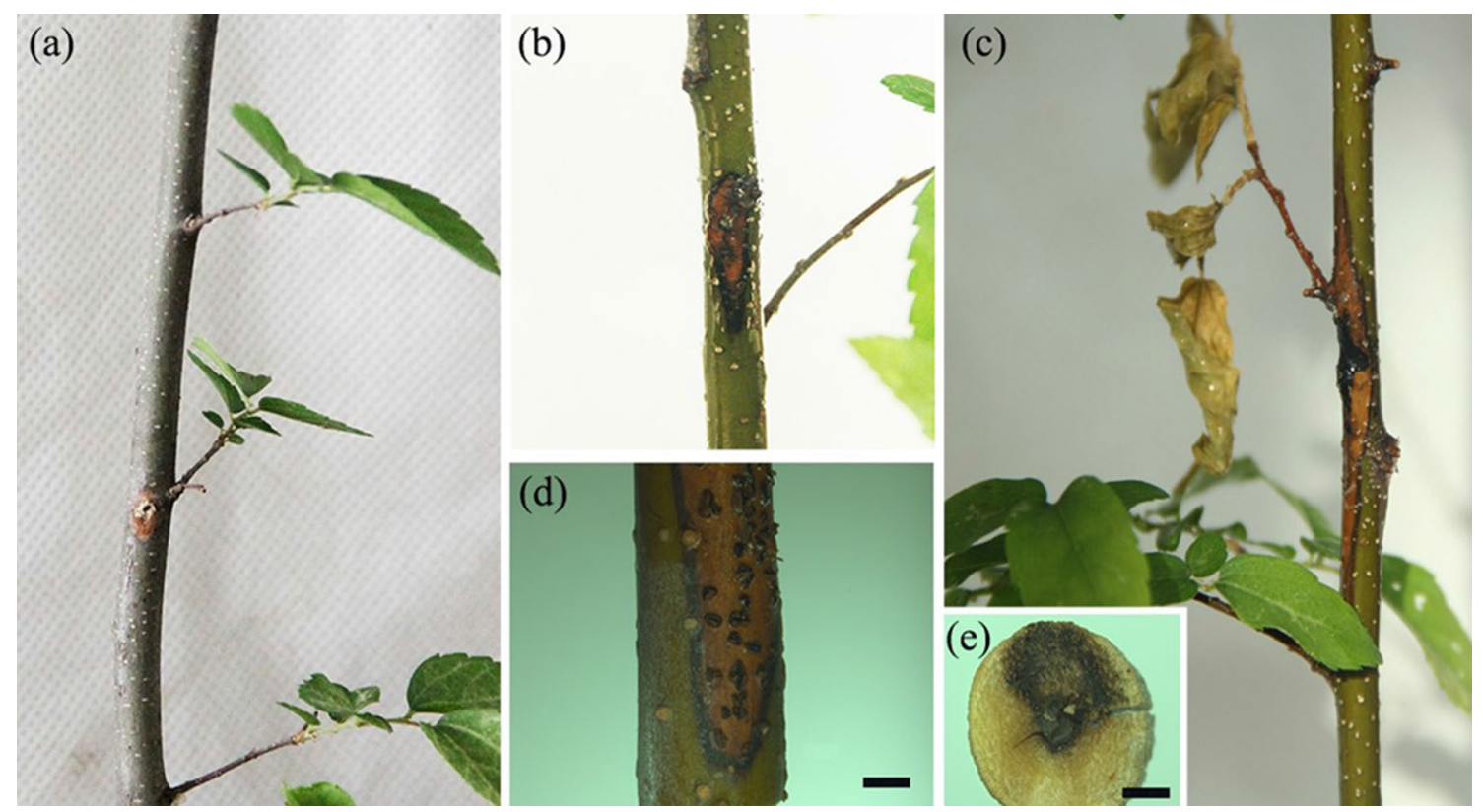

Fig. 2 Results of the pathogenicity trial. a Control stem (not inoculated with L. pseudothebromae). b Symptoms at the early stage, reddish brown spots and canker developing around the inoculation sites.
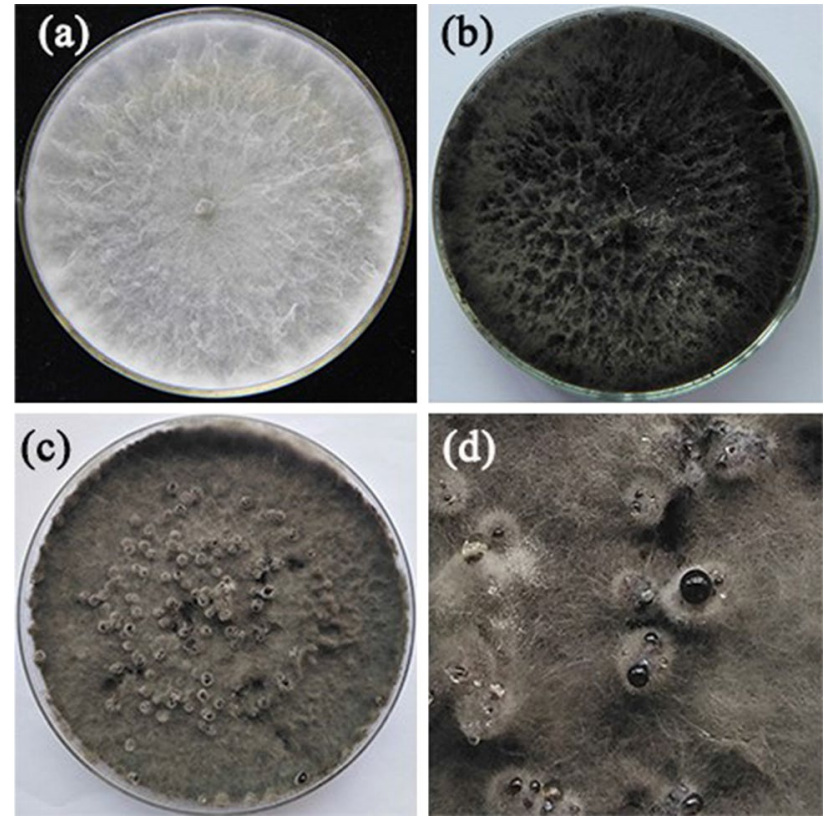

Fig. 3 Colony characteristics for L. pseudotheobromae isolate Ls7. a 4-day-old white to light-cream colony. b 7-day-old dark gray colonies, fluffy aerial mycelium. $\mathbf{c}$ Pycnidia produced under an ultraviolet lamp. d Liquid secretions may mark the open position of the conidia

blunt, wider in the middle, initially transparent and aseptate or not partitioned (Fig. 4f). These had one septum and became puce after maturity; melanin appeared in the conidia and the surface was striped (Fig. 4g, h). [A condium c Symptoms at a later stage; typical canker symptoms of Chinese hackberry 35 days after stem inoculation. d Mature conidiomata on the disease site in this disease. $\mathrm{e}$ Xylem discoloration $(\operatorname{Bars}=500 \mu \mathrm{m})$

accompany with partial germ tube (Fig. 4i)]. The sizes of conidia were $22.2-28.6 \times 12.1-17.4 \mu \mathrm{m}$ (95\% confidence limits $=25.2 \pm 2.6 \times 14.4 \pm 2.4)$ and the average conidia length-width ratio was approximately 1.7 (Table 1 ). The paraphyses were hyaline and upward cylindrical. (Fig. 4b). In addition, the Ls7 isolate grew at $10^{\circ} \mathrm{C}$ and produced dark pink colonies at $35{ }^{\circ} \mathrm{C}$ (Fig. 5). The morphological characteristics of the Ls7 isolate fit those of L. pseudotheobromae (Alves et al. 2008) and therefore confirmed as L. pseudotheobromae causing Chinese hackberry canker.

\section{Molecular identification of pathogen}

After PCR amplification, the Ls7 isolate with primers ITS1/ ITS4, EF1-1251r/EF1-688f, BT2a/BT2b and rpb2-LasR/ rpb2-LasF, segment sizes of 544, 315, 462 and 532 bp were acquired, respectively. The sequence accession numbers in GenBank were registered as MH454038.1, MH746713, MK041547 and MK069598, respectively. The ITS sequence of the test pathogen revealed $100 \%$ homology with L. pseudotheobromae in GenBank of BLAST search.

Before the establishment of phylogenetic trees with four groups of gene links, two tree-building methods were used to sequence and analyze individual gene sequences. There were no obvious conflicts in a single gene phylogeny and the ITS, tefl- $\alpha, T U B$ and $r p b 2$ datasets can be amalgamated. Sequences downloaded from NCBI (National Center for Biotechnology Information) were then used to carry out 

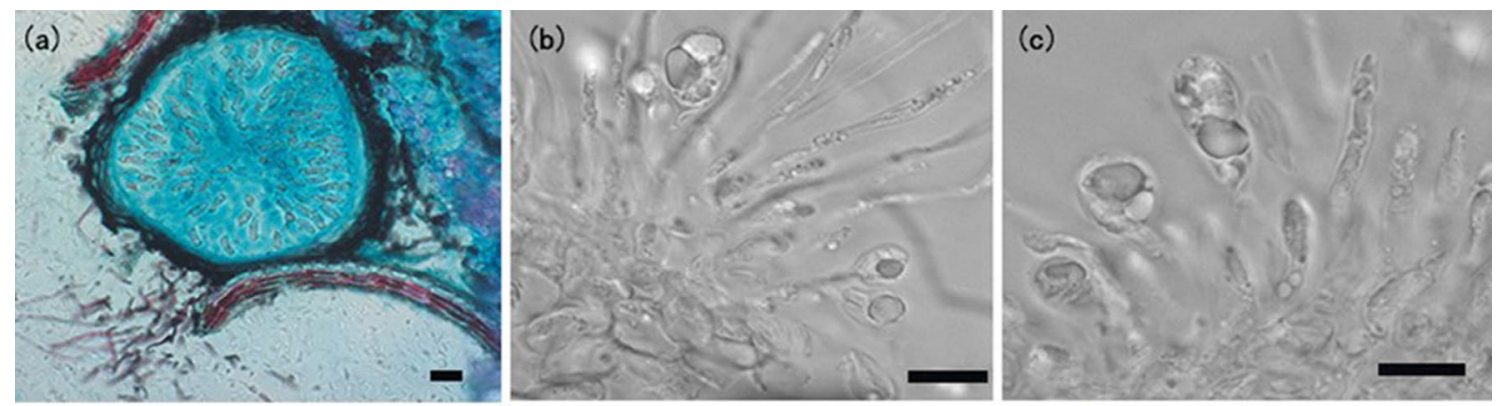
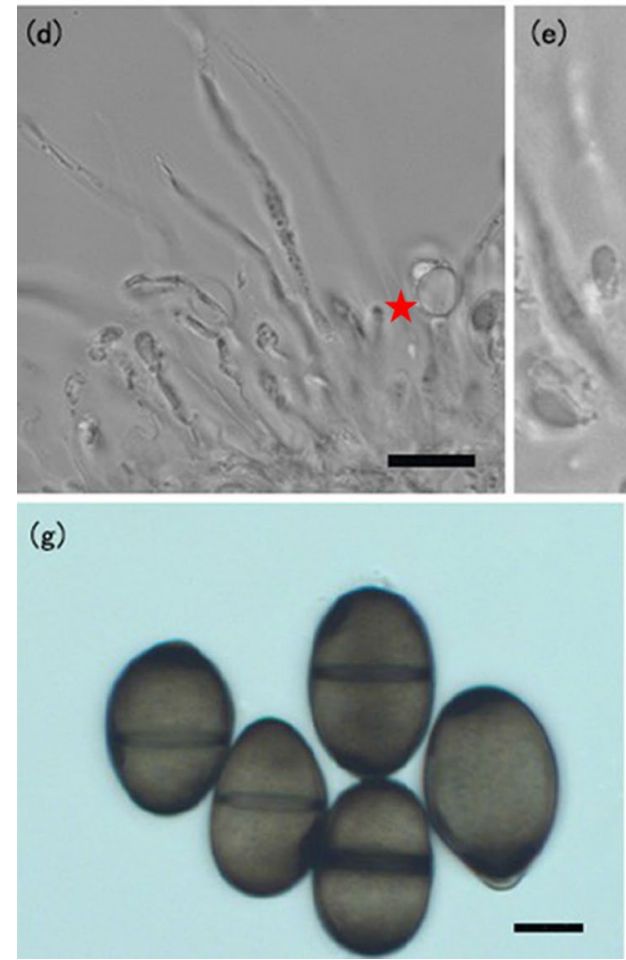

(e)

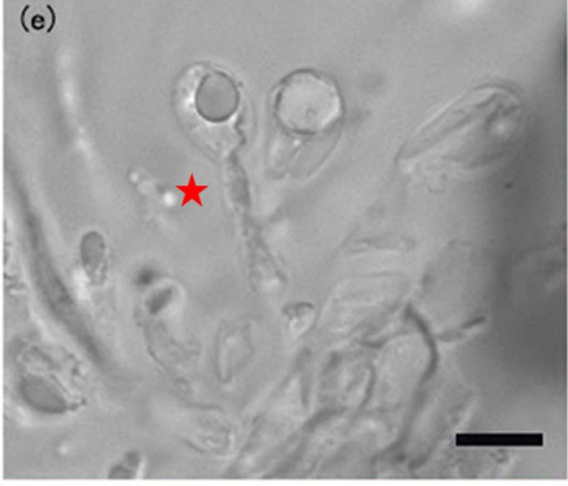

(h)

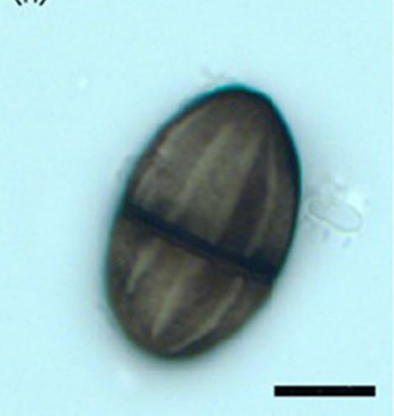

(f)

(i)
Fig. 4 Conidial morphological characteristics for L. pseudotheobromae isolate Ls7 seen under the light microscope. a Pycnidia. b Paraphyses. c, d Conidiogenous cell. d, e Conidiophore (red star). f Hyaline, aseptic conidia. $\mathbf{f}-\mathbf{h}$ Septate, melanin deposits on the inner surface of the wall arranged longitudinally giving a striate appearance to the conidia. i A condium with partial germ tube (Bars $=10 \mu \mathrm{m})$
Table 1 Conidia measurement of Lasiodiplodia pseudotheobromae isolates from Chinese hackberry and comparison with previous studies

\begin{tabular}{lllll}
\hline Isolate & Host & Mean $\pm \mathrm{SD}(\mu \mathrm{m})$ & L/W & Source \\
\hline Ls7 & Chinese hackberry & $25.2 \pm 2.6 \times 14.4 \pm 2.4$ & 1.7 & This study \\
HMQAU 140073 & Blueberry & $25.7 \pm 1.6 \times 14.2 \pm 1.4$ & 1.7 & Wang et al. (2016) \\
Type & Gmelina arborea & $28 \pm 2.5 \times 16 \pm 1.2$ & $1.7 \pm 0.2$ & Alves et al. (2008) \\
\hline
\end{tabular}

cluster analysis (Dou et al. 2017). The Diplodia mutila isolate CMW7060 was selected as an out-group (Table 2).

A phylogenetic tree based on ITS, tefl- $\alpha, T U B$ and RPB2 sequences was constructed by cluster analysis of the gene sequences of the test pathogen and other Lasiodiplodia species complex strains (number of sites $=410$, bootstrap replicates $=1000$ ). The results show that isolates of Lasiodiplodia sp. were clearly divided into several clades or groups with a common ancestor representing different species within Lasiodiplodia. The test isolate showed high homology with $L$. pseudotheobromae (Fig. 6). Therefore, the isolate was confirmed to be L. pseudotheobromae on the grounds of molecular identification. 


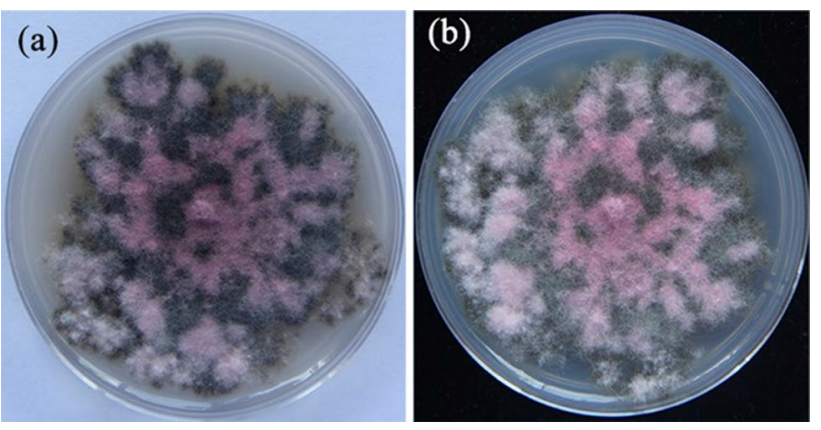

Fig. 5 Fungus isolate Ls7 a unique dark pink colony under incubation at $35^{\circ} \mathrm{C}$. a Colony on white background. b Colony on black background

\section{Discussion}

Based on available knowledge, this is the first report of Chinese hackberry stem canker disease caused by L. pseudotheobromae in China. The twigs and stems of all infected seedlings became cankerous and turned black, which was devastating to Chinese hackberry plantations.

Lasiodiplodia pseudotheobromae is important in agriculture and forestry as it causes cankers, stem-end rot, dieback and fruit rot (Sakalidis et al. 2011; Ismail et al. 2012; Marques et al. 2013). These diseases lead to bark discolouration, browning of medullary tissue, a decline in growth, and drying of leaves on upper branches. In severe cases, they may even lead to plant death (Alves et al. 2004), resulting in considerable economic losses. The pathogen overwinters in the soil, and in the summer of the following year, conidia and conidiomata are spread by wind and rain (Yee et al. 2019).

Worldwide, this species has a wide range. L. pseudotheobromae is an aggressive species in Australia, Cameroon, Egypt, Brazil, Mexico, China and other countries (Begoude et al. 2010; Sakalidis et al. 2011; Ismail et al. 2012; Maricarmen et al. 2013; Coutinho et al. 2016). In China, it is mainly distributed in central and eastern portions of the country, including Beijing, Jiangsu, Hubei, Sichuan, and Shandong (Li and $\mathrm{Li}$ 2015).

At the same time, it has a wide range of hosts. It causes stem-end rot or dieback in branches of mango (Kwon et al. 2017), papaya stem-end rot (Netto et al. 2014), English walnut stem canker ( $\mathrm{Li}$ et al. 2016), blueberry dieback (Wang et al. 2016), pedicel and peduncle discoloration of grapes (Dissanayake et al. 2015), and Eucalyptus cankers (Chen et al. 2011) in China. In addition, it also can infect Acacia confusa Merr (Dou et al. 2017), Anacardium occidentale
L., Citrus, Coffea and Gmelina species (Phillips et al. 2008; Abdollahzadeh et al. 2010; Perez et al. 2010; Sakalidis et al. 2011; Slippers et al. 2014; Trakunyingcharoen et al. 2015; Coutinho et al. 2016), Albizia falcataria (L.), Paulownia spp., Mangifera sylvatica, Eucalyptus spp. and grapevine etc. (Alves et al. 2008; Zhao et al. 2010; Dissanayake et al. 2015).

This study focused on a Chinese hackberry canker disease outbreak between July and August. The maximum temperature tolerated by $L$. pseudotheobromae was $54{ }^{\circ} \mathrm{C}$ this resistance to high temperatures enables it to survive during the summer months. The disease spreads rapidly and is most severe during summers when temperatures reaches $30{ }^{\circ} \mathrm{C}$ and above (Zhang 2012). In other seasons the disease is less aggressive (Wu et al. 2018).

Conidia exist all year-round but are rarely detected in winter (Xu et al. 2014). The pathogen overwinters in the diseased twigs or soil and becomes the source of infection the following year, with spores travelling by means of wind, rain and insects (Wu et al. 2001). The pycnidia or fruiting body of the fungus is produced near the canker before spreading to neighboring hosts. Pathogens commonly enter the plant through wounds left by pruning of twigs and this may be the main reason for the spread of the disease. The presence of the disease cannot be ignored as it leads to significant economic losses in forestry and agriculture (Wang 2016). Therefore, control measures should be carried out in the early stage of discovery of the disease.

In the genus Lasiodiplodia, L. pseudotheobromae is phylogenetically close to $L$. theobromae (Li et al. 2018). Although they are closely related, the size and shape of $L$. pseudotheobromae conidia differ from those of $L$. theobromae which are larger and have orbicular ends (Alves et al 2008). In addition, L. pseudotheobromae can also grow at $10{ }^{\circ} \mathrm{C}$ and form deep-pink colonies at $35^{\circ} \mathrm{C}$ but $L$. theobromae does not (Marques et al. 2013; Netto et al. 2014). The fungal samples categorized as Ls7 type in this study showed similar features with L. pseudotheobromae and was consistent with these characteristics.

Based on the phylogenetic relationship of $\beta$-tubulin, Cheng (2012) concluded that the sexual stage of L. pseudotheobromae may be Botryosphaeria rhodina. In 2016, Tennakoon et al. (2016) found the sexual morph of L. pseudotheobromae collected from dead leaves of Plukenetia volubilis L. (Euphorbiaceae) in Yunnan Province, China. Using phylogenetic analyses based on ITS and tefl- $\alpha$ sequence data, they authenticated the sexual-asexual connection in L. pseudotheobromae. It was the first evidence in molecular genetics of a sexual morph for this species. However, the sexual morph of the Ls7 isolate was not found in this study. 
Table 2 GenBank accession numbers for ITS, tefl- $\alpha, T U B$ and RPB2 sequence data for Lasiodiplodia species used in this study

\begin{tabular}{|c|c|c|c|c|c|c|}
\hline \multirow[t]{2}{*}{ Species } & \multirow[t]{2}{*}{ Cultures } & \multicolumn{4}{|l|}{ GenBank } & \multirow[t]{2}{*}{ Locality } \\
\hline & & ITS & tefl- $\alpha$ & $T U B$ & $R P B 2$ & \\
\hline L. avicenniae & CMW41467 & KP860835 & KP860680 & KP860758 & KU587878 & South Africa \\
\hline avicenniae & LAS199 & KU587957 & KU587947 & KU587868 & KU587880 & South Africa \\
\hline L. bruguierae & CMW41470 & KP860833 & KP860678 & KP860756 & KU587875 & South Africa \\
\hline L. bruguierae & CMW42480 & KP860832 & KP860677 & KP860755 & KU587876 & South Africa \\
\hline L. chinensis & CGMCC3.18061 & KX499889 & KX499927 & KX500002 & KX499965 & China \\
\hline L. citricola & IRAN1522C & GU945354 & GU945340 & KU887505 & KU696351 & Iran \\
\hline L. citricola & IRAN1521C & GU945353 & GU945339 & KU887504 & KU696350 & Iran \\
\hline L. crassispora & WAC12533 & DQ103550 & DQ103557 & KU887506 & KU696353 & Australia \\
\hline L. crassispora & CMW13488 & DQ103552 & DQ103559 & KU887507 & KU696352 & Venezuela \\
\hline L. gilanensis & IRAN1523C & GU945351 & GU945342 & KU887511 & KU696357 & Iran \\
\hline L. gilanensis & IRAN1501C & GU945352 & GU945341 & KU887510 & KU696356 & Iran \\
\hline L. gonubiensis & CMW14077 & AY639595 & DQ103566 & DQ458860 & KU696359 & South Africa \\
\hline L. gonubiensis & CMW14078 & AY639594 & DQ103567 & EU673126 & KU696358 & South Africa \\
\hline L. hormozganensis & IRAN1500C & GU945355 & GU945343 & KU887515 & KU696361 & Iran \\
\hline L. hormozganensis & IRAN1498C & GU945356 & GU945344 & KU887514 & KU696360 & Iran \\
\hline L. mahajangana & CMW27801 & FJ900595 & FJ900641 & FJ900630 & KU696365 & Madagascar \\
\hline L. mahajangana & CMW27818 & FJ900596 & FJ900642 & FJ900631 & KU696366 & Madagascar \\
\hline L. iraniensis & IRAN1520C & GU945348 & GU945336 & KU887516 & KU696363 & Iran \\
\hline L. iraniensis & IRAN1502C & GU945347 & GU945335 & KU887517 & KU696362 & Iran \\
\hline L. mediterranea & CBS 137,783 & KJ638312 & KJ638331 & KU887521 & KU696368 & Italy \\
\hline L. mediterranea & CBS 137,784 & KJ638311 & KJ638330 & KU887522 & KU696369 & Italy \\
\hline L. missouriana & UCD2193MO & HQ288225 & HQ288267 & HQ288304 & KU696370 & USA \\
\hline L. missouriana & UCD2199MO & HQ288226 & HQ288268 & HQ288305 & KU696371 & USA \\
\hline L. parva & CBS 456.78 & EF622083 & EF622063 & KU887523 & KU696372 & Colombia \\
\hline L. parva & CBS 494.78 & EF622084 & EF622064 & EU673114 & KU696373 & Colombia \\
\hline L. plurivora & STE-U 5803 & EF445362 & EF445395 & KU887524 & KU696374 & South Africa \\
\hline L. plurivora & STE-U 4583 & AY343482 & EF445396 & KU887525 & KU696375 & South Africa \\
\hline L. pseudotheobromae & CBS 116,459 & EF622077 & EF622057 & EU673111 & KU696376 & Costa Rica \\
\hline L. pseudotheobromae & UFRPE CFS 048 & MG870583 & MG870575 & MG870603 & MG870613 & Pernambuco/Paraiba \\
\hline L. pseudotheobromae & CGMCC 3.18047 & KX499876 & KX499914 & KX499989 & KX499952 & China \\
\hline L. pseudotheobromae & Ls7 (this study) & MH454038 & MH746713 & MK041547 & MK069598 & China \\
\hline L. pyriformis & CBS121770 & EU101307 & EU101352 & KU887527 & KU696378 & Namibia \\
\hline L. rubropurpurea & WAC12535 & DQ103553 & DQ103571 & EU673136 & KU696380 & Australia \\
\hline L. rubropurpurea & WAC12536 & DQ103554 & DQ103572 & KU887530 & KU696381 & Australia \\
\hline L. theobromae & CBS 164.96 & AY 640255 & AY 640258 & KU887532 & KU696383 & Papua New Guinea \\
\hline L. theobromae & CBS 111,530 & EF622074 & EF622054 & KU887531 & KU696382 & Unknown \\
\hline L. venezuelensis & WAC12539 & DQ103547 & DQ103568 & KU887533 & KU696384 & Venezuela \\
\hline L. viticola & UCD 2553AR & HQ288227 & HQ288269 & HQ288306 & KU696385 & USA \\
\hline L. viticola & UCD 2604MO & HQ288228 & HQ288270 & HQ288307 & KU696386 & USA \\
\hline L. vitis & CBS 124,060 & KX464148 & KX464642 & KX464917 & KX463994 & Italy \\
\hline Diplodia mutila & CMW 7060 & AY236955 & AY236904 & AY236933 & EU339574 & Netherlands \\
\hline
\end{tabular}

Extype isolates were in bold (Dou et al. 2017) 
Fig. 6 Phylogenetic tree based on combined rDNA-ITS, tefl- $\alpha$, $T U B$ and $R P B 2$ gene sequences of Chinese hackberry Lasiodiplodia stem canker pathogen and related fungi. Bootstrap support values from 1000 bootstrap replications are showed. Outgroup: Diplodia mutila

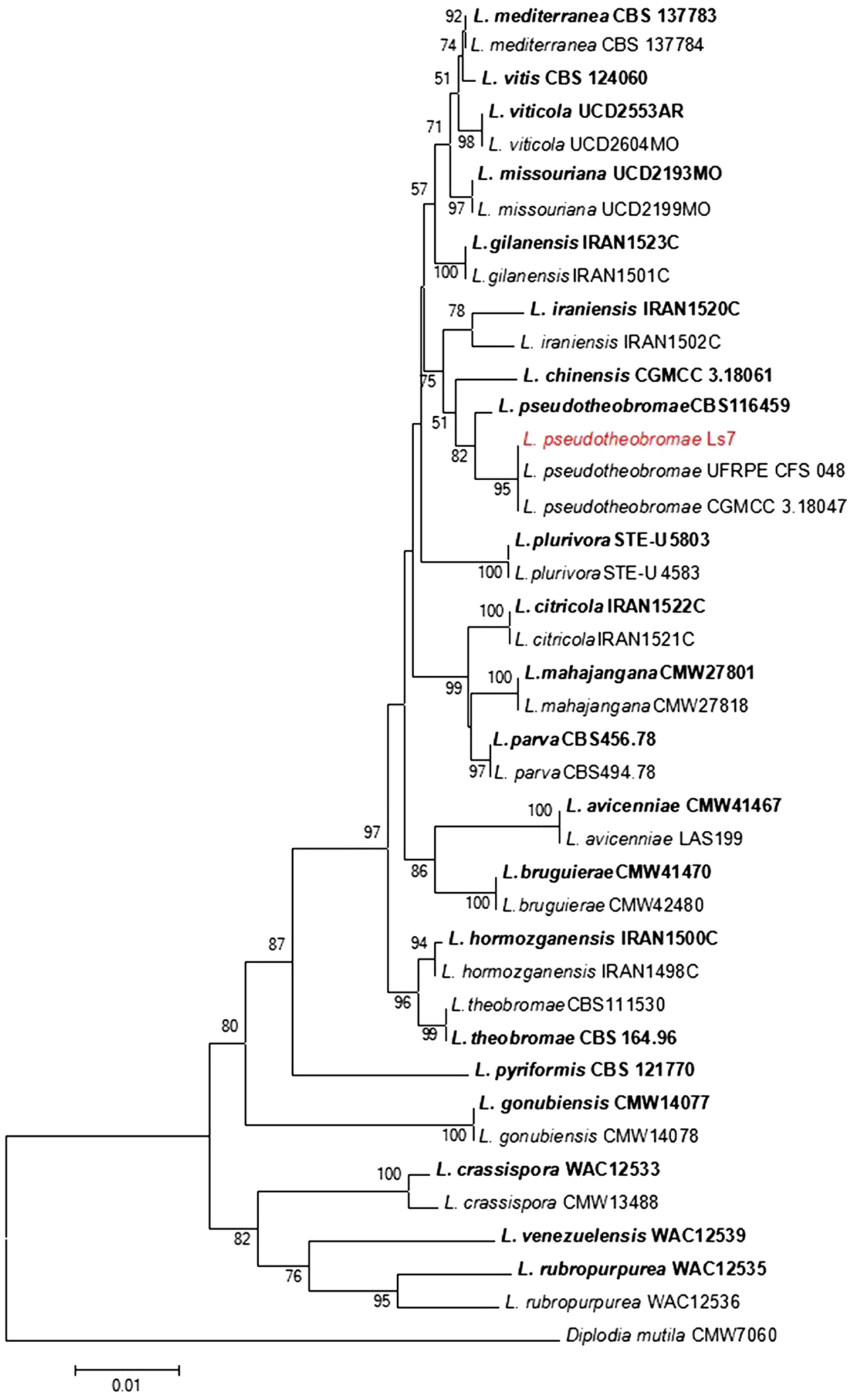




\section{Conclusions}

This is the first report of hackberry canker in China and Chinese hackberry (C. sinensis) is a new host of L. pseudotheobromae. The occurrence of the disease should be closely monitored and preventative measures put in place to avoid the spread of the disease. This study may provide reference value for the prevention of Chinese hackberry canker.

Open Access This article is distributed under the terms of the Creative Commons Attribution 4.0 International License (http://creativecommons.org/licenses/by/4.0/), which permits unrestricted use, distribution, and reproduction in any medium, provided you give appropriate credit to the original author(s) and the source, provide a link to the Creative Commons license, and indicate if changes were made.

\section{References}

Abdollahzadeh J, Javadi A, Mohammadi Goltapeh E, Zare R, Phillips AJL (2010) Phylogeny and morphology of four new species of Lasiodiplodia from Iran. Persoonia 25(1):1-10

Alves A, Correia ACM, Luque J, Phillips AJL (2004) Botryosphaeria corticola, sp. nov. on Quercus species, with notes and description of Botryosphaeria stevensii and its anamorph, Diplodia mutila. Mycologia 96(3):598-613

Alves A, Crous PW, Correia A, Phillips AJL (2008) Morphological and molecular data reveal cryptic speciation in Lasiodiplodia theobromae. Fungal Divers 28(2):1-13

Begoude BAD, Slippers B, Wingfield MJ, Roux J (2010) Botryosphaeriaceae associated with Terminalia catappa in Cameroon, South Africa and Madagascar. Mycol Prog 9(1):101-123

Berbegal M, Pérez-Sierra A, Armengol J (2012) First report of Sirosporium celtidis causing a foliar disease of European hackberry in Spain. Plant Dis 96(12):1826

Cacciola SO (2000) A foliar disease of European hackberry endemic in Sicily. Plant Dis 84(4):492

Cao WJ (2017) Based on the analysis of Chinese hackberry maintenance technology in winter. NONGJIA KEJI 9:211

Chen SF, Pavlic-Zupanc D, Roux J, Slippers B, Xie YJ, Wingfield MJ, Zhou XD (2011) Characterization of Botryosphaeriaceae from plantation-grown Eucalyptus species in South China. Plant Pathol 60(4):739-751

Cheng YL (2012) Phylogeny of some Botryosphaeriaceae species and genetic diversity of type Botryosphaeria dothidea in China. Ph.D. dissertation, Chinese Academy of Forestry, pp 1-101

Correia K, Silva MA, De Morais MA, Armengol J, Phillips AJL, Camara MPS, Michereff SJ (2016) Phylogeny, distribution and pathogenicity of Lasiodiplodia species associated with dieback of table grape in the main Brazilian exporting region. Plant Pathol 65(1):92-103

Coutinho IBL, Freire FCO, Lima CS, Lima JS, Goncalves FJT, Machado AR, Silva AMS, Cardoso JE (2016) Diversity of genus Lasiodiplodia associated with perennial tropical fruit plants in northeastern Brazil. Plant Pathol 66(1):90-104

Cruywagen CW, Brisson GJ, Tremblay GF, Meissner HH (2016) Effect of curd suppression in a milk replacer on physiological parameters in calves. I digestibility of nutrients and body massgain. S Afr J Anim Sci 20:234-238
Dai SL, Lin J, Gao L (2007) Brief report on antibacterial activity of penicillin and streptomycin in PDA medium. Edible Fungi China 26(04):53-54

Dissanayake AJ, Zhang W, Liu M, Chukeatirote E, Ye J, Li XH, Hyde KD (2015) Lasiodiplodia pseudotheobromae causes pedicel and peduncle discolouration of grapes in China. Australas Plant Dis Notes 10(1):21

Dou ZP, He W, Zhang Y (2017) Lasiodiplodia chinensis, a new holomorphic species from China. Mycosphere 8(4):521-532

Glass NL, Donaldson GC (1995) Development of primer sets designed for use with the PCR to amplify conserved genes from filamentous ascomycetes. Appl Environ Microbiol 61:1323-1330

Ismail AM, Cirvilleri G, Polizzi G, Crous PW, Groenewald JZ, Lombard L (2012) Lasiodiplodia species associated with dieback disease of mango (Mangifera indica) in Egypt. Australas Plant Pathol 41:649-660

Kwon JH, Choi O, Kang B, Lee Y, Park J, Kang DW, Han I, Kim J (2017) Identification of Lasiodiplodia pseudotheobromae causing mango dieback in Korea. Can J Plant Pathol 39:241-245

Lee CK, Lee SH, Seo ST, Cho SE, Shin HD (2019) First report of powdery mildew caused by Pleochaeta shiraiana on Celtis biondii in Korea. Plant Dis 103(6):1429-1429

Li X, Li WY (2015) Biodiversity of Lasiodiplodia species in China. In: Proceedings of annual conference of the Chinese Society of Mycology, 2015

Li GQ, Liu FF, Li JQ, Liu QL, Chen SF (2016) Characterization of Botryosphaeria dothidea and Lasiodiplodia pseudotheobromae from English walnut in China. J Phytopathol 164(5):348-353

Li GQ, Liu FF, Li JQ, Liu QL, Chen SF (2018) Botryosphaeriaceae from eucalyptus plantations and adjacent plants in China. Persoonia 40:63-95

Luongo L, Haegi A, Galli M, Berti S, Vitale S, Belisario A (2015) First report of Phytophthora megasperma causing decline and death on Celtis australis in Italy. Plant Dis 99(1):155

Maricarmen S, Angel DN, Sandoval-Islas JS, Ortiz DT, Orozco-Santos M, Silva-Rojas HV (2013) Hongos asociados a pudrición del pedúnculo y muerte descendente del mango (Mangifera indica L.). Agrociencia 47(1):61-73

Marques MW, Lima NB, Morais Júnior MAD, Barbosa MAG, Souza BO, Michereff SJ, Phillips AJL, Câmara MPS (2013) Species of Lasiodiplodia associated with mango in Brazil. Fungal Divers 61(1):181-193

Netto MSB, Assuncao IP, Lima GSA, Marques MW, Lima WG, Monteiro JHA, Balbino VQ, Michereff SJ, Phillips AJL, Camara MPS (2014) Species of Lasiodiplodia associated with papaya stem-end rot in Brazil. Fungal Divers 67(1):127-141

Pavlic D (2004) Botryosphaeria species on native South African Syzygium cordatum and their potential threat to Eucalyptus. M.Sc. dissertation, University of Pretoria, Pretoria, pp 1-130

Perez CA, Wingfield MJ, Slippers B, Altier NA, Blanchette RA (2010) Endophytic and canker-associated Botryosphaeriaceae occurring on non-native Eucalyptus and native Myrtaceae trees in Uruguay. Fungal Divers 41:53-69

Phillips AJL, Alves A, Pennycook SR, Johnston PR, Ramaley A, Akulov A, Crous PW (2008) Resolving the phylogenetic and taxonomic status of dark-spored teleomorph genera in the Botryosphaeriaceae. Persoonia 21:29-55

Phillips AJL, Alves A, Abdollahzadeh J, Slippers B, Wingfield MJ, Groenewald JZ, Crous PW (2013) The Botryosphaeriaceae: genera and species known from culture. Stud Mycol 76:51-167

Saitou N, Nei M (1987) The neighbor-joining method: a new method for reconstructing phylogenetic trees. Mol Biol Evol 4:406-425

Sakalidis ML, Hardy GESJ, Burgess TI (2011) Endophytes as potential pathogens of the baobab species Adansonia gregorii: a focus on the Botryosphaeriaceae. Fungal Ecol 4:1-14 
Slippers B, Roux J, Wingfield MJ, van der Walt FJJ, Jami F, Mehl JWM, Marais GJ (2014) Confronting the constraints of morphological taxonomy in the Botryosphaeriales. Persoonia 33:155-168

Tamura K, Peterson D, Peterson N, Stecher G, Nei M, Kumar S (2011) Mega5: molecular evolutionary genetics analysis using maximum likelihood, evolutionary distance, and maximum parsimony methods. Mol Biol Evol 28:2731-2739

Tennakoon DS, Phillips AJL, Phookamsak R, Ariyawansa HA, Bahkali AH, Hyde KD (2016) Sexual morph of Lasiodiplodia pseudotheobromae (Botryosphaeriaceae, Botryosphaeriales, Dothideomycetes) from China. Mycosphere 7(7):990-1000

Trakunyingcharoen T, Lombard L, Groenewald JZ, Cheewangkoon R, To-anun C, Crous PW (2015) Caulicolous Botryosphaeriales from Thailand. Persoonia 34:87-99

Wang XY (2016) The identification of pathogens for 17 fungal diseases of 14 ornamental plants. Ph.D. dissertation, South China Agricultural University, pp 1-58

Wang JN, Zhao HH, Yu YY, Li XD, Liang C, Li BD (2016) The pathogen causing Lasiodiplodia twig blight of blueberry. Mycosystema 35:657-665

White TJ, Bruns T, Lee S, Taylor J (1994) Amplification and direct sequencing of fungal ribosomal RNA Genes for phylogenetics. PCR Protoc 38:315-322

Wu XQ, He YQ, Liu ZH (2001) Occurrence and progress on tree cankers caused by Botryosphaeria spp. J Nanjing For Univ 25(1):61-66
Wu HR, Li ZP, Sun XYQ, Zhang Y, Ding JY, Cheng LL (2018) Identification and biological characteristics of the pathogen causing stinking root rot of rubber tree. Chin J Trop Crops 39(5):940-947

Xu CN, Chi FM, Ji ZR, Dong QL, Zhang HJ, Cao KQ, Zhou ZS (2014) Research progress of Botryosphaeriaceae with dieback of blueberry. China Fruits 5:71-74

Yee JK, Latiffah Z, Masratul HM (2019) Lasiodiplodia species associated with Sansevieria trifasciata leaf blight in Malaysia. J Gen Plant Pathol 85:66-71

Zhang L (2012) Global forest pest health profile: a case study under the global forest resources assessment 2005. China Agricultural Press, Beijing

Zhang YH, Wei DS, Xing LJ, Li MC (2008) A modified method for isolating DNA from fungus. Microbiology 3:466-469

Zhao JP, Lu Q, Liang J, Decock C, Zhang XY (2010) Lasiodiplodia pseudotheobromae, a new record of pathogenic fungus from some subtropical and tropical trees in southern China. Cryptogam Mycol 31(4):431-439

Publisher's Note Springer Nature remains neutral with regard to jurisdictional claims in published maps and institutional affiliations. 